\title{
INTEGRASI CSR DAN PROGRAM PERENCANAAN PEMBANGUNAN DAERAH DALAM KERANGKA MEWUJUDKAN MODEL BARU PELAKSANAAN CSR
}

\author{
Oleh \\ M. Lukman Hakim \\ Ketua Laboratorium Pemerintah dan Perencanaan Daerah (eLppeda) \\ dan Dosen IPM Universitas Brawijaya Malang
}

\begin{abstract}
Implementation of the concept of corporate social responsibility (CSR) is mainly not coincided with the local government policy.The local government development planner (Bappeda) designs its policy according to national plan and budget from the central government, whereas the company's CSR team is doing "business as usual" regardless whether its program's design match with the government plan or not. Consequently, many of CSR projects do not reach satisfactory outcome as it clashed with governments' projects. A number of programs such as poverty alleviation, greening, and strengthening local economies that the company does are often collide with those from government. If there is a match, it leads to a double budgeting of same target place or a double counting in a program budget. This situation adds to the long list of classic local planning issues which is overlapping programs among government agencies. Hence, the implementation of CSR and the design of regional planning that are intended to further advance the regional development has often resulted in disappointment. An obvious example of this argument is in the case of PT Kalimantan Prima Coal (KPC) which operates in Kabupaten of Kutai Timur. Despite the fact that the district has a regional budget of Rp. 2.4 trillion, which is $86 \%$ of it obtained from the mine and mostly came from the royalty ofKPC, but the development process of the region is considered relatively slow. Many consider local government has failed in carrying out the development goal, whereas KPC is considered only want to make profits and ignoring the well-being of surrounding community.This paper argues that in order to find solution of this impasse formulation and a new conception is needed to integrate the company's CSR program with the development plan set out by the local government. By doing so, a new model of CSR is expected to be successfully implemented.
\end{abstract}

Keywords: CSR, Local Development Plan, KPC

\section{A. LATAR BELAKANG}

Tanggungjawab

Sosial

Perusahaan atau yang lazim disebut (CSR) kini semakin diterima kalangan pengusaha, sebagai suatu 'kewajiban' yang harus dijalankan,beriringan dengan langkah-langkah mencapai profit.
Para pengusaha menyadari bahwa perusahaan tidaklah sekedar entitas ekonomi semata, tetapi juga institusi $\operatorname{sosial}^{10}$, yang berada dalam suatu

\footnotetext{
${ }^{10}$ Istilah CSR mulai digunakan sejak tahun 1970an dan semakin populer terutama setelah kehadiran buku Cannibals With Forks: The Triple Bottom Line in 21st Century Business (1998), karya John Elkington. Mengembangkan tiga
} 
lingkungan sosial, dan membawa serta tanggungjawab sosial yang tinggi. Dalam pandangan ini, perusahaan secara moral mempunyai tanggungjawab terhadap semua pihak dan profitabilitas hanyalah sarana untuk melakukan tanggungjawab tersebut ${ }^{11}$.

Namun demikin tidak sedikit kalangan yang menganggap CSR sebagai beban, kalaupun menjalankan hanya sekedar gugur kewajiban. Dengan membagikan sembako atau melakukan sunatan massal setahun sekali, perusahaansudah merasa menjalankan CSR. Sejumlah perusahaan juga menjalankan CSR berdasarkan "copy-paste design" atau sekadar "menghabiskan" anggaran. Karena aspirasi dan kebutuhan masyarakat kurang diperhatikan, beberapa program CSR di satu wilayah menjadi seragam dan seringkali tumpang tindih.

Alih-alih memberdayakan masyarakat, CSR malah berubah menjadi Candu (menimbulkan ketergantungan pada masyarakat), Sandera (menjadi alat masyarakat memeras perusahaan) dan Racun

komponen penting sustainable development, yakni economic growth, environmental protection, dan social equity, yang digagas the World Commission on Environment and Development (WCED) dalam Brundtland Report (1987), Elkington mengemas CSR ke dalam tiga fokus: 3P, singkatan dari profit, planet dan people. Lih: Pearce and Robinson. 2005. Formulation, Implementation, and Control of Competitive Strategy. New York: McGraw-Hill Irwin, p; 43. Bandingkan dengan

${ }^{11}$ Pandangan yang lain menyebutkan bahwa profitabilitas adalah tujuan utama dari perusahaan dan tanggungjawab sosial yang harus ditanggung hanyalah yang masuk dalam kerangka hukum terkait dengan keberadaan perusahaan tersebut Dalam pandangan ini CSR bukanlah suatu kewajiban yang harus dilakukan, lih; Bob de Wit and Ron Meyer. 2004. Strategy: Process, Content, Context - 3rd Ed. London: Thomson Learning, p; 87 (merusak perusahaan dan masyarakat).

Selain masalah-masalah pelaksanaan CSR yang berdampak sektoral di atas, sejumlah masalah lain dan dampaknya lebih luas mengiringi pelaksanaan CSR. Ketiadaan integrasi kebijakan perencanaan pembangunan pemerintah dan pelaksanaan program CSR, membuat pelaksanaan keduanya tidak terencana, tidak inetegratif, dan tidak tepat sasaran.

Para perancang pembangunan pemerintah berjalan sesuai dengan pagu perencanaan yang telah di amanatkanundang-undang ${ }^{12}$,

sementara para pelaksana CSR perusahaan berjalan sesuai dengan jadwal program yang telah ditetapkan.

Akibatnya pelaksanaan CSR tidak tepat sasaran; Sejumlah program seperti pengentasan kemiskinan, penghijauan, dan penguatan ekonomi lokal yang dilakukan Tim CSR Perusahaan tak jarang berbenturan dengan perencanaan dan program pemerintah daerah. Kalaupun terjadi kesesuaian, justru berujung pada penganggaran ganda di tempat yang sama (doublle counting) dalam satu program anggaran.

Situasi ini menambah daftar panjang persoalan perencanaan ${ }^{13}$

\footnotetext{
${ }^{12}$ Peraturan Mentri Dalam Negeri No 54 Tahun 2010 tentang Tahapan Tatacara Penyusunan, Pengendalian, dan Evaluasi Pelaksanaan Rencana Pembangunan Daerah

13 Tidak semua negara percaya pentingnya perencanaan dalam proses pembangunan. Sejumlah negara maju, seperti Amerika dan banyak negara di Eropa, tidak mengenal model perencanaan, hanya negara-negara sedang berkembang dan negara penganut paham sosialis yang percaya dengan model perencanaan dalam mendorong proses pembangunan di negaranya. Lih; Syafrizal, 2009. Teknis Praktis Penyusunan
} 
daerah yang kerap tumpang tindih antara satu Dinas/Badan dengan Dinas/Badan lain. Sehingga pelaksanaan CSR dan desain perencanaan daerah yang dimaksudkan untuk semakin memajukan proses pembangunan tak pernah bisa berjalan.

Potret hitam tidak sinergisnya CSR dengan kebijakan perencanaan pembangunan pemerintah di atas terjadi di Kabupaten Kutai Timur. Sekalipun Kabupaten ini memiliki anggaran daerah hingga Rp. 2,4 trilliun yang $85,17 \%$ diperoleh dari hasil tambang - utamanya royalty Batu bara PT Kaltim Prima Coal (KPC), namun proses pembangunan berjalan sangat lamban. Pemerintah Daerah dinilai gagal dalam melaksanakan amanat pembangunan, sementara KPC dianggap hanya mengeruk keuntungan, dan tidak perduli dengan nasib dan kondisi masyarakat sekitar.

Kondisi masyarakat (etnis) Kutai yang hidup di pinggir-pinggir sungai dengan mata pencaharian mengandalkan sumberdaya alam seperti mencari madu, damar, rotan, ikan, bertani, dll sebelum KPC melakukan aktivitas pertambangan pada tahun 1992, kini telah berubah. Rotanhilang dan punah, madu, damar sudah sangat sulit didapatkan.

Air sungai Sangatta yang dulu sangat jernih, ikan dan udang masih bisa dilihat, dan kedalamannya mencapai 15 m,kini telah berubah menjadi keruh dan berlumpur, tidak bisa diminum karena rasanya agak asam, terjadi pendangkalan sungai, sehingga kedalamannya sekarang hanya mencapai $5 \mathrm{~m}$.

Pembangunan Daerah, Baduose Media, Padang, hal; 117
Situasi sosial ekologis ini menurut warga sekitar disatu sisi tak pernah diperhitungkan dalam pelaksanaan CSR. Bahkan banjir akibat guyuran hujan yang menggelontor dataran tinggi yang sudah gundul kini mulai terjadi.

Disisi lain pajak-pajak yang disetor KPC seperti royalti, sewa tetap/lumpsum, pajak lain-lain selalu meningkat setiap tahun karena kenaikan jumlah produksi batu bara. Laba perusahaan juga selalu meningkat setiap tahun, namun alokasi dana CSR relatif tetap. Peningkatan hanya terjadi sekali yaitu sebelum tahun 2005, KPC mengalokasikan dana CSR sebesar US $\$ 1,5$ juta/th. Setelah tahun 2005 dengan munculnya SKB Bupati Kutim dan Presdir BR, KPC ${ }^{14}$ mengalokasikan dana CSRnya sebesar US\$ 5 juta/th dengan rekomendasi alokasi sejumlah US\$ 1,5 juta/th dipegang oleh Forum MSH CSR $^{15}$ dan US\$ 3,5 juta/th dikelola langsung manajemen KPC.

Peningkatan anggaran CSR tersebut sayangnya tidak berdampak pada peningkatan program dan pembangunan daerah. Hal ini lebih dikarenakan anggaran CSR hanya dibagi ke elit politik-pemerintahan, bukan dipersatukan dalam sebuah

\footnotetext{
${ }^{14}$ Surat Keputusan Bersama antara Bupati Kutai Timur (Mahyudin) dan Presiden Direktur KPC No.43/02.188.45/HK/II/2005 tanggal 21 Februari 2005 menetapkan bahwa:Pertama, PT. Bumi Resources (BR) melalui KPC akan mengalokasikan anggaran sebesar US\$ 5.000.000 (setiap tahun) yang merupakan dana kemitraan (CSR) kepada pihak di luar perusahaan dan diharapakan dapat berperan dalam membantu pelaksanaan pembangunan Kutim.Kedua, Membentuk Tim Pendamping Pengelola Dana Kemitraan KPC.

${ }^{15}$ Forum Multi Stakeholder CSR (MSH CSR) dibentuk melalui Keputusan Bupati Kutai Timur No. 71/02.188.45/HK/III/2006.
} 
perencanaan (program CSR dan Perencanaan Daerah) yang integratif.

Pada tahun 2006dana CSR bahkandigunakan untuk pengamanan perusahaan, berbarengan dengan saat pemerintah menetapkan KPC sebagai Objek Vital Nasional (Obvitnas).

Pendek kata, sejumlah program CSR yang dijalankan KPC belum sepenuhnya dapat memberikan nilai tambah bagi program pembangunan daerah. Perencanaan pembangunan yang merupakan suatu cara, tekhnik, atau suatu metode untuk mencapai tujuan yang diinginkan secara tepat, terarah, efesien dan mengintegrasikan sumber daya yang ada ${ }^{16}$ berakhir dengantidak efesien,berjalan sendiri-sendiri dan dimungkin terjadi kolusi serta korupsi.

\section{B. METODOLOGI}

Penulisan makalah ini menggunakan metode Critical discourse analysis (CDA) atau yang lazim disebut Analisis Wacana Kritis model Foucault. CDA adalah tipe analisis wacana yang terutama sekali mempelajari bagaimana kekuasaan disalahgunakan, atau bagaimana dominasi serta ketidakadilan dijalankan dan direproduksi melalui teks dalam sebuah konteks sosial politik.

Dalam CDA Foucault wacana tidak dipahami semata sebagai studi bahasa. Sekalipun pada akhirnya,

16 Proses tersebut akan terlaksana apabila asumsi-asumsi pembangunan dapat terpenuhi, meliputi; kesempatan kerja atau partisipasi termanfaatkan secara penuh (full employment), setiap pelaku pembangunan mempunyai kemampuan yang sama (equal production) dan masing-masing pelaku bertindak secara efisien. Lih; Michel Todaro. 1971. Development Planing: Models and Methods. Nairobi: Oxford University Press, p: 117 analisis wacana memang menggunakan bahasa dalam teks untuk dianalisis. Bahasa dianalisis bukan dengan menggambarkan semata dari aspek kebahasaan, tetapi juga menghubungkan dengan konteks. Konteks disini berarti bahasa itu dipakai untuk tujuan dan praktik tertentu, termasuk di dalamnya $\operatorname{praktik~kekuasaan}^{17}$.

Pendek kata analisis wacana kritis melihat wacana-pemakaian bahasa dalam tuturan dan tulisansebagai bentuk praktik sosial ${ }^{18}$. Menggambarkan wacana sebaga praktik sosial menyebabkan sebuah hubungan dialektis di antara peristiwa diskursif tertentu dengan situasi, institusi, dan struktur sosial yang membentuknya. Melalui wacana, sebagai contoh, keadaan yang rasis, seksis, atau ketimpangan dari kehidupan sosial dipandang sebagai suatu common sense, kewajaran alamiah $^{19}$.

Karakteristik penting dari analisis wacana kritis adalah; a) tindakan; b) konteks; c) historis $;^{20}$; d) kekuasaan; e) dan ideologi ${ }^{21}$.

\footnotetext{
17 Eriyanto, 2001. Analisis Wacana Pengantar Analisis Teks Media, LkiS, Yogyakarta, hal. 7

${ }^{18}$ Wodak, R. (2001). What CDA is about - a summary of its history, important concepts, and its development. In Methods of CDA. (ed.) by R. Wodak and M. Meyers. London: Sage Publication, 1-13.

${ }^{19}$ Fairclough N., 2000, ì Discourse, social theory and social research: the discourse of welfare reformî, Journal of Sociolinguistics 4, pp. 163-195

${ }^{20}$ Ibid, hal.10-11

21 Van Dijk, T. A. (1998). Ideology. A Multidisciplinary Study. London: Sage. P: 265
} 


\section{PERTAMBANGAN KUTAI TIMUR}

Kabupaten Kutai Timur adalah salah satu daerah di Kalimantan Timur yang kaya akan sumber tambang seperti batu bara, migas, emas, nikel, besi, platina, perak, batu gamping, lempung, pasir kuarsa dan gipsum.

Gambar di samping menunjukkan pertambangan Kabupaten Kutai Timur terdapat di wilayah Sangkima (Migas) Sengatta Utara (Batu Bara) Muara Ancalong, Muara Wahau dan Telen (Emas). Dan masih banyak lagi wilayah lain yang kandungan batu bara dan minyak dan gas buminya melimpah.

Bahan tambang berupa batubara merupakan salah satu komoditas yang menonjol-menjadi andalan Kabupaten Kutai Timur. Selama kurun 2006-2010produksi batu bara mencapai 189,355.779 M.Ton atau rata-rata produksi pertahun mencapai $37,871.154$ M.Ton.

\section{Tabel 1 Produksi Pertambangan}

Batu Bara Tahun 2006 - 2010

Sementara produksi minyak bumi yang dieksploitasi mencapai $3.251,830$ barrel dengan rata-rata produksi mencapai 812,932 barrel per tahun sedangkan jumlah produksi gas Alam mencapai 26.921,511 Mscf dengan rata-rata produksi $6.733,778$ Mscf per tahun.

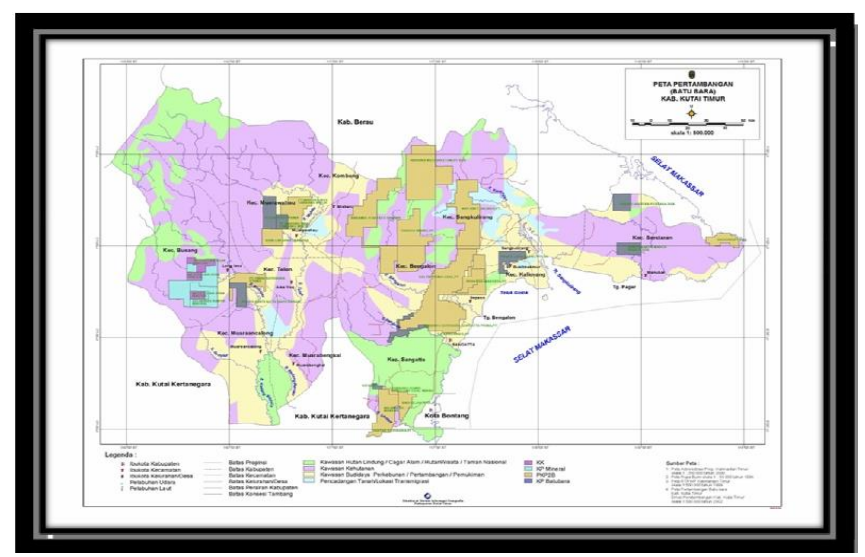

Gambar1. Kawasan Pertambangan Kab. Kutai Timur Sumber: Dokumen RTRW Kabunaten Kutai Timur

\begin{tabular}{cccccccc}
\hline No & $\begin{array}{c}\text { Golonga } \\
\mathrm{n}\end{array}$ & Satuan & 2006 & 2007 & 2008 & 2009 & $2010^{*}$ \\
\hline 1. & Batu & M.Ton & 49.532 .959 & 31.162 .250 & 37.430 .531 & 54.248 .842 & 16.981 .197 \\
\hline
\end{tabular}

Sumber : Simreda Kabupaten Kutai

Timur 2011

Tabel 2 Produksi Minyak bumi dan Gas alam Tahun 2006 - 2010

\begin{tabular}{ccccccccc}
\hline No & $\begin{array}{c}\text { Jenis } \\
\text { Komoditas }\end{array}$ & Satuan & $\mathbf{2 0 0 6}$ & $\mathbf{2 0 0 7}$ & $\mathbf{2 0 0 8}$ & $\mathbf{2 0 0 9}$ & $\mathbf{2 0 1 0}$ \\
\hline 1. & $\begin{array}{c}\text { Minyak } \\
\text { Bumi }\end{array}$ & 000 Barrel & - & 808,99 & 937,58 & 707,37 & 797,89 \\
\hline 2. & Gas Alam & 000 Mscf & - & $6.584,96$ & $7.684,95$ & $6.138,841$ & $6.512,76$ \\
\hline
\end{tabular}


Sumber: SimredaKabupaten Kutai Timur Tahun 2011

Data di atas menunjukkan tingginya ketergantungan Kabupaten Kutai Timur pada hasil tambang, Kondisi ini dengan sendirinya memengaruhi perekonomian Kabupaten Kutai Timur. Sektor pertambangan dan penggalian terutama batubara menjadi pendukung utama perekonomian Kabupaten Kutai Timur. Dominasi subsektor ini ditandai dengan masih tingginya peranan pertambangan batubara tahun 2006-2011 antara $80,27 \%$ sampai $81,58 \%$, dan diperkirakan pada tahun 2012 konstribusinya sebesar $81,53 \%$ dari total PDRB Kabupaten Kutai Timur dengan Migas.

Nilai PDRB Kabupaten Kutai Timur atas dasar harga berlaku dengan migas pada tahun 2006-2010 secara otomatiscenderung meningkat, berbanding lurus dengan PDRB tanpa migas dan batu bara yang juga mengalamipeningkatan.

Sementara itu,sektor yang kontribusinya cukup besar setelah sektor Pertambangan dan Penggalian adalah sektor Pertanian ${ }^{22}$. Seiring dengan masih dominannya peran sektor Pertambangan dan Penggalian dalam beberapa tahun terakhir, peranan sektor ini relatif stabil antara $4,29 \% \quad-\quad 5,04 \%, \quad$ sedangkan

\footnotetext{
${ }^{22}$ Berdasarkan PDRB tanpa migas dan batubara tahun 2006-2010, sektor pertanian merupakan yang paling dominan dalam pembentukan PDRB dengan kontribusi antara29,01\%-29,23\%. Urutan terbesar kedua adalah sektor perdagangan, hotel, dan restoran dengan share antara 21,34\%-23,59\%, kemudian disusul sektor bangunan sebesar antara 15,46\% $16,01 \%$. Sedangkan sektor-sektor lainnya, dibawah $14 \%$. Subsektor pekebunan merupakan penyumbang terbesar pada sektor pertanian dengan share antara 5,36\%-10,68\%.
}

sumbangan sektor-sektor lainnya masih dibawah $4 \%$.

Gambar 2

Rata-rata Distribusi PDRB Atas

Dasar Harga Berlaku Dengan

Migas Dan Batu bara Menurut

Lapangan Usaha Tahun 2006-2010

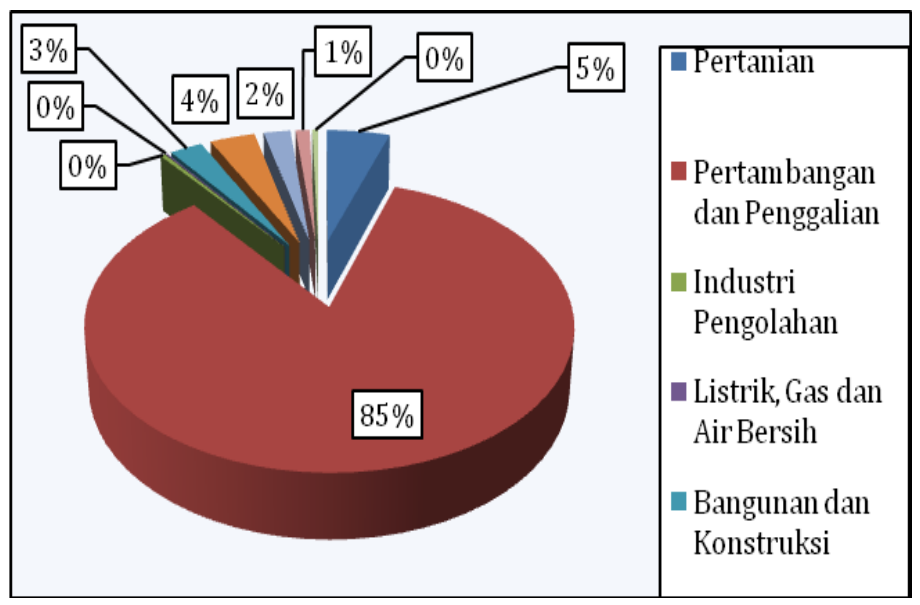

Sumber: RPJMD Kabupaten

Kutai Timur Tahun 2011-2015

Kekayaan sumberdaya pertambangan ini menjadi magnet bagi sejumlah raksasa perusahaan pertambangan seperti Kaltim Prima Coal (KPC) yang penandatanganan PKP2B kali pertama dilakukan pada 2 April 1982.

KPC mulai beroperasi penuh tahun 1992 dan masa konsesinya akan berakhir pada tahun 2021. Awalnya KPC dimiliki oleh Beyound Petroleum (BP) dan Rio Tinto dengan pembagian saham masing-masing $50 \%$. Berdasarkan akta No.9 tanggal 6 Agustus 2003 dan bukti pelaporan dari menteri kehakiman tanggal 11 Agustus 2003, saham KPC yang dimiliki BP dan Rio Tinto telah di akuisisi kepada Kalimantan Coal Ltd dan Sangatta Holding Ltd. Tanggal 18 Oktober 2005, Bumi Resources telah mengakuisisi saham Kalimantan 
Coal Ltd dan Sangatta Holding. Data profil KPC hingga Desember 2006 menyebutkan bahwa kepemilikan saham KPC adalah 95\% milik Bumi Resources $^{23}$ dan 5\% milik Perusda PT. Kutai Timur Energi ${ }^{24}$.

Berdasarakan perjanjian karya yang ditandatangani, KPC memiliki wilayah konsesi 90.938 ha. Pada tahun $2006 \quad$ KPC mengoperasikan tambang batu bara terbuka di 8 pit di Sengata dan 1 pit di Bengalon. 5 pit dioperasikan KPC dan 4 pit lainnya oleh kontraktor yaitu Thiess, Pama dan Dharma Henwa.

Dari kegiatan penambangan tersebut, 352,3 Mbcm batuan penutup dipindahkan untuk memperoleh 38,2 juta ton batu bara. 96,43\% Batu bara hasil produksi KPC dijual untuk keperluan pasar interbasional sementara hanya 3,53\% yang dijual di dalam negeri. Pada tahun 2013KPC meningkatkan produksinya dari 40 juta ton (2011) menjadi 70 juta ton.

\section{PROGRAM CSR KPC}

PT KPC kali pertama melaksanakan CSR pada awal 1990an yang saat itu dikenal dengan istilah Community Development (CD). Program CSR dilaksanakan dalam bentuk pembangunan sarana ibadah, beasiswa untuk anak sekolah,

${ }^{23} \mathrm{PT}$. Bumi Resources (BR) merupakan perusahaan pertambangan yang berada di bawah bendera Kelompok Bakrie. Visi Perusahaan ini menjadi perusahaan kelas dunia dalam sektor pertambangan dan energi.

${ }^{24}$ PT. Kutai Timur Energi adalah Perusahaan Daerah dengan pimpinan Mahyudin mantan Bupati Kutim tahun 2005. 5\% saham yang diberikan kepada Perusda PT. Kutai Timur Energi merupakan saham hibah dari BR hasil negosiasi. pengobatan gratis, bibit tanaman pertanian seperti pisang, sawit, jeruk, dan lain-lain. Selain itu, KPC juga terlibat dalam memberikan dukungan pada perayaan hari-hari besar agama. Pelaksanakan program CSR juga diberikan dalam bentuk bantuan pembangunan sekolah, pembuatan

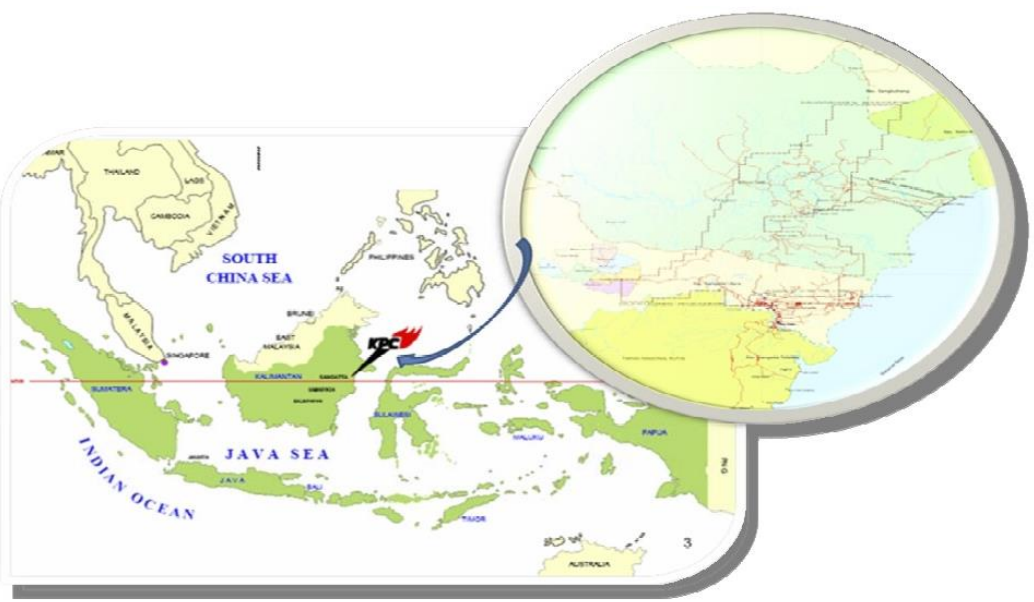

Gambar 3. Wilayah Konsesi PT KPC

Sumber: Summary Eksekutif AMDAL KPC 2005

jalan dan penyediaan air bersih.

Menurut Divisi Ekstenal

Sustainable Development (ESD)

KPC, factor yang mendorong perusahaan pertambangan ini melaksanakan CSR adalah: untuk memenuhi kewajiban persyaratan AMDAl; Mendapatkan 'social license to operat'e dari masyarakat ; Ingin menerapkan prinsip 'good corporate citizenship' dalam bisnis; dan bertanggungjawab pasca tambang pada 2021.

Karena itu kemudian PT KPC menetapkan Visi“Menjadi mitra dalam pembangunan berkelanjutan dan meningkatkan kualitas hidup masyarakat". Visi ini diturunkan menjadi tiga misi ${ }^{25}$. Kemudian

\footnotetext{
${ }^{25}$ Misi KPC adalah; a) menjalin hubungan yang harmonis dengan pemangku kepentingan berdasarkan prinsip saling percaya dan saling menghargai; b) mendorong pertumbuhan perekonomian lokal yang saling menguntungkan
} 
berdasarkan misi tersebut PT KPC menetapkan tujuh bidang program CSR, beserta pendanaanya sebagaimana table di bawah ini ${ }^{26}$

\section{Tabel 3 Program Pembangunan 7 Bidang}

\begin{tabular}{clc}
\hline No & \multicolumn{1}{c}{ Program Kegiatan } & Jumlah (US\$) \\
\hline 1 & Pengembangan agribisnis & 138.851 \\
\hline 2 & Kesehatan Masyarakat & 178.366 \\
\hline 3 & Pendidikan dan Pelatihan & 299.665 \\
\hline 4 & Pemberdayaan ekonomi local & 78.740 \\
\hline 5 & Pembangunan infrastruktur & 1.883 .041 \\
\hline 6 & Pelestarian alam dan budaya & 46.535 \\
\hline 7 & Peningkatan kapasitas masyarakat & 910.548 \\
\hline 8 & Program melalui Pemkab Kutim & 1.024 .561 \\
\hline 9 & Biaya Operasional & 77.219 \\
\hline & Total & $\mathbf{4 . 5 9 7 . 5 2 6}$ \\
\hline
\end{tabular}

Sumber: Surat Keputusan Bersama antara Bupati Kutai Timur (Mahyudin) dan Presiden Direktur KPC No.43/02.188.45/HK/II/2005 tanggal 21 Februari 2005

Penyusunan prioritas pengalokasian dana CSR di atas dilakukan KPC berdasarkan logika dampak. Apakah daerah tersebut menerima dampak langsung atau tidak langsung dari operasional KPC.

\section{Gambar 4}

\section{Logika Prioritas dan Peta Sebaran} CSR PT. KPC

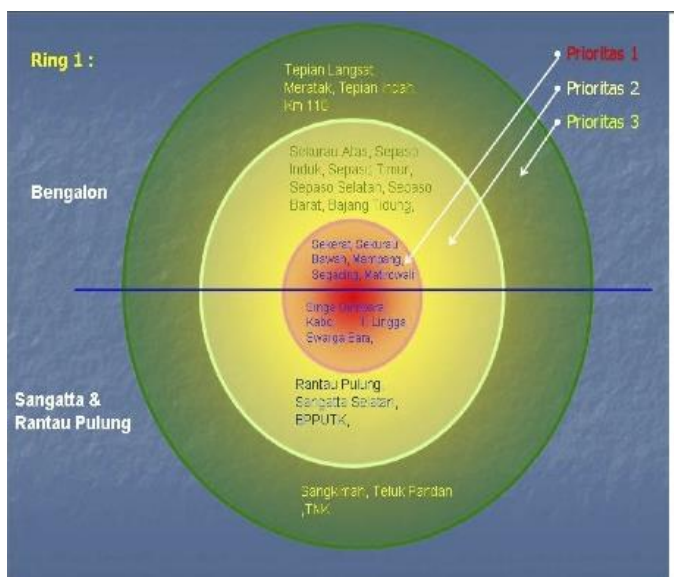

Sebagaimana gambar di atas Lingkar/ Ring 1 merupakan daerah yang menerima dampak langsung dari operasi pertambangan yang dilakukan oleh KPC. Pada ring 1 ini terdapat 3 tingkatan prioritas daerah yaitu Sengata Utara, Bengalon, Sengata Selatan, Rantau Pulung, Sangkimah, Teluk Pandan. Setelah ring 1 akan diikuti oleh ring 2 yang tingkat dampak yang diterima tidak sebesar ring 1. Lingkar/Ring 2 terdiri dari Kutai Timur (di luar Sangatta, Bengalon dan Rantau Pulung). Selanjutnya diikuti oleh Lingkar/Ring

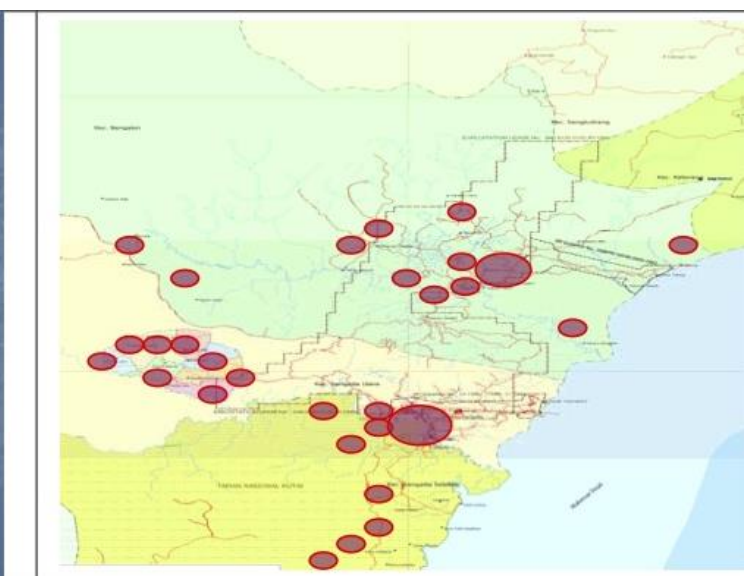


3 yaitu Kaltim dan seterusnya diikuti oleh Lingkar/Ring 4 yaitu wilayah Nasional.

\section{E. MODEL BARU CSR}

Sekalipun CSR dijalankan sejak pertengahan 1990an namun hingga kini masih belum bisa diintegrasikan dengan proses perencanaan pembangunan pemerintah. Selama ini CSR dilaksanakan secara langsung oleh perusahaan di bawah divisi human resource development atau public relations. CSR kadang juga dijalankan oleh yayasan yang dibentuk terpisah dari organisasi induk perusahaan namun tetap harus bertanggung jawab ke CEO atau ke dewan direksi.

Seperti halnya KPC, sebagian besar perusahaan di Indonesia menjalankan CSR melalui kerjasama dengan mitra lain, seperti LSM, perguruan tinggi atau lembaga konsultan. Beberapa perusahaan ada pula yang bergabung dalam sebuah konsorsium untuk secara bersamasama menjalankan CSR. Beberapa perusahaan bahkan ada yang menjalankan kegiatan serupa CSR, meskipun tim dan programnya tidak secara jelas berbendera CSR.

Pada awal perkembangannya, bentuk CSR yang paling umum adalah pemberian bantuan terhadap organisasi-organisasi lokal dan masyarakat miskin di negara-negara berkembang. Pendekatan CSR yang berdasarkan motivasi karitatif dan kemanusiaan ini pada umumnya dilakukan secara ad-hoc, parsial, dan tidak melembaga. CSR pada tataran ini hanya sekadar do good dan to look good, berbuat baik agar terlihat baik. Perusahaan yang melakukannya termasuk dalam kategori "perusahaan impresif", yang lebih mementingkan "tebar pesona" (promosi) ketimbang "tebar karya" (pemberdayaan) ${ }^{27}$

Dewasa ini semakin banyak perusahaan yang kurang menyukai pendekatan karitatif semacam itu, karena tidak mampu meningkatkan keberdayaan atau kapasitas masyarakat lokal. Pendekatan communitydevelopment kemudian semakin banyak diterapkan karena lebih mendekati konsep empowerment dan sustainable development. Prinsip-prinsip good corporate governance, seperti fairness, transparency, accountability, dan responsibility kemudian menjadi pijakan untuk mengukur keberhasilan program CSR.

Sekalipun saat makalah ini ditulis kegiatan CSR yang dilakukan sudah mulai beragam, disesuaikan dengan kebutuhan masyarakat setempat berdasarkan needs assessment, tapi masih dalam kerangka berjalan sendiri tanpa integrasi perencanaan dengan proses pembangunan pemerintah setempat.

Karena itu sejak tahun 2007 muncul kesadaran pemerintah yang ditandai dengan penegasan "pemwajiban" CSR bagi perusahaan sebagaimana tertuang di dalam Pasal 74 ayat 1 Undang-undang 40 Tahun 2007 tentang Perseroan Terbatas.

Kelemahan UU ini adalah tidak menyebutkansecara rinci berapa besaran biaya yang harus dikeluarkan perusahaan untuk CSR serta sanksi bagi yang melanggar. ${ }^{28}$

\footnotetext{
${ }^{27}$ Edi. Suharto, 2008 Menggagas Standart Audit CSR, dalam Round Table Discussion AAI

${ }^{28}$ Pada ayat 2, 3 dan 4 UU No 40 Tahun 2007 hanya menyebutkan bahwa CSR "dianggarkan dan diperhitungkan sebagai biaya perseroan yang pelaksanaannya dilakukan dengan memperhatikan kepatutan dan kewajaran".
} 
Baru pada tanggal 4 April 2012 pemerintah menetapkan Peraturan Pemerintah No 47 Tahun 2012 tentang Tanggungjawab Sosial dan Lingkungan Perseroan Terbatas. Sebagaimana tertuang dalam filosofi perundangannya, PP ini dimaksudkan untuk melaksanakan ketentuan Pasal 74 UU No 40 Tahun 2007 tentang Perseroan Terbatas.

Penamaan PP ini juga telah mengakomodir perdebatan yang selama ini berkembang, dimana CSR dianggap belum mengkover tanggung jawab lingkungan. Dengan adanya PP ini, dan sanksi serta aturan pelaksanaanya yang lebih jelas, masa depan pelaksanaan CSR di Indonesia menjadi lebih pasti.

Namun demikian, persoalan dan perdebatan yang menyelimuti CSR tidak kunjung usai. Di tingkat global misalnya, pro dan kontra CSR serta kontradiksi-kontradiksi penerapan CSR menimbulkan perdebatan panjang.Tragedy lingkungan yang ditimbulkan perusahaan ekstraktif yangeksploitatif (macam KPC) dinilai tidak sebanding dengan CSR yang diberikan.

Peraturan lain yang menyentuh CSR adalah UU No.25 Tahun 2007 tentang Penanaman Modal. Pasal 15 (b) menyatakan bahwa "Setiap penanam modal berkewajiban melaksanakan tanggung jawab sosial perusahaan." Meskipun UU ini telah mengatur sanksi-sanksi secara terperinci terhadap badan usaha atau usaha perseorangan yang mengabaikan CSR (Pasal 34), UU ini baru mampu menjangkau investor asing dan belum mengatur secara tegas perihal CSR bagi perusahaan nasional.

Peraturan tentang CSR juga diatur dalam UU No.19 Tahun 2003 tentang BUMN. UU ini kemudiaan dijabarkan lebih jauh oleh Peraturan Menteri Negara BUMN No.4 Tahun 2007 yang mengatur mulai dari besaran dana hingga tatacara pelaksanaan CSR. Saying, UU inipun masih menyisahkan masalah. Selain hanya mengatur BUMN, program kemitraan perlu dikritisi sebelum disebut sebagai kegiatan CSR.
Untuk mengurai persoalan di atas diperlukan upaya yang sungguhsungguh dalam menampilkan atau melaksanakan CSR. Caranya adalah dengan mengintegrasikan program CSR perusahaan dengan perencanaan pembangunan yang dirumuskan pemerintah.

Integrasi ini menjadi penting sebab perencanaan pembangunan merupakan; a) usaha pemerintah secara terencana dan sistemik untuk mengendalikan dan mengatur proses pembangunan, b) mencakup periode jangka panjang, menengah, dan tahunan, c) menyangkut Variabelvariabel yang memengaruhi pertumbuhan ekonomi dan pembangunan secara keseluruhan baik secara langsung maupun tidak langsung, d) mempunyai suatu sasaran pembangunan yang jelas sesuai dengan keinginan masyarakat ${ }^{29}$

Sejumlah variable di atas sejalan dengan definisi perencanaan pembangunan yang dikemukan sejumlah pakar. Lewis AW mendefinisikan perencanaan pembangunan sebagai "suatu kumpulan kebijaksanaan dan program pembangunan untuk merangsang masyarakat dan swasta untuk menggunakan sumber daya yang tersedia secara lebih produktif.,30 Sementara itu Jhingan M.L. seorang ahli perencanaan pembangunan asal India memberikan definisi yang lebih

\footnotetext{
${ }^{29}$ Undang-undang Nomor 25 Tahun 2004 tentang Sistem Perencanaan Pembangunan Nasional

${ }^{30}$ Rangsang-rangsangan tersebut menurut Arthur harus diberikan dalam bentuk insentifinsentif ekonomi baik secara mikro maupun makro yang dapat mendorong penggunaan sumber daya secara lebih produktif sehingga proses pembangunan akan lebih meningkat. Lewis Arthur, 1965. Development Planing, New York, Harper Row, p: 321
} 
kongkrit tentang perencanaan pembangunan tersebut yaitu: Perencanaan pembangunan pada dasarnya merupakan pengendalian dan pengaturan perekonomian dengan sengaja oleh pemerintah untuk mencapai suatu sasaran dan tujuan tertentu di dalam jangka waktu tertentu pula. ${ }^{31}$

Dalam konteks integrasi perencanaan pembangunan Kabupaten Kutai Timur, definisi perencanaan pembangunan UUSPPN, 2004 tampak lebih pas, yakni proses untuk menentukan tindakan masa depan yang tepat, melalui urutan pilihan, dengan memperhitungkan sumberdaya yang tersedia.

Program dan dana CSR yang begitu besar, sebagaimana dijelaskan di atas, merupakan salah satu sumber daya yang harus dimaksimalkan untuk mencapai $2000 \quad 2005$ target pembangunan.

\section{Maksimalisa} si sumber daya sedianya dimulai sejak pemerintah Kabupaten Kutai Timur merumsukan perencanaan pembangunannya mulai dari Rencana Pembangunan

jangka Panjang Daerah (RPJPD), Rencana Tata Ruang Wilayah (RTRW), Rencana Pembangunan Jangka Menengah
Daerah (RPJMD), dan Rencana Kerja Pemerintah Daerah (RKPD).

Dokumen-dokumen

perencanaan di atas sedianya memasukkan integrasi perencanaan dan program CSR perusahaan, apalagi di dalam skenario jangka panjang Kabupaten Kutai Timur telah dirumuskan rencana pembangunan pasca tambang dengan asumsi masa kerja tambang diperkirakan akan habis pada tahun 2021. Rencana pembangunan pasca tambang meliputi; pengembangan industri di luar industri tambang, pelayanan jasa dan potensi agribisnis yang selama ini belum optimal dimanfaatkan, di samping kelautan, manufaktur, barang dan jasa, serta pariwisata.

\section{Gambar 5}

Skenario Pengembangan Jangka

Panjang Kabupaten Kutai Timur 
Dalam skenario pembangunan pasca tambang di atas terdapat sejumlah periodesasi, yakni; Periode pertama, merupakan periode inisiasi dimana komitmen pembangunan Kabupaten Kutai Timur telah dituangkan dalam Rencana Strategis Kabupaten Kutai Timur 2001-2005. lebih luas. Hal ini diperkuat dengan Visi di dua periode pemerintahan sebagaimana tabel di bawah ini:

Tabel 4 Visi-misi Pemerintah Daerah Kutai Timur Periode 20062010 dan 2011-2015

\section{PERENCANA \\ AN \\ VISI}

PembangunanDaerah yang bertumpu pada pembangunan yang

Periode

(2006-2010) berkeadilan menuju masyarakat Kutai Timur yang sejahtera dengan memanfaatkan sumberdaya alam yang dapat diperbarui dan menjadikan daerah Kabupaten Kutai Timur sebagai pusat agribisnis dan agroindustri di Kalimantan Timur

\begin{tabular}{ll}
\hline Periode & Pembangunan Daerah Bertumpu Pada Agribisnis Menuju Kutai \\
$(2011-2015)$ & Timur Mandiri
\end{tabular}

Sebagai langkah awal dalam periode pembekalan dasar dari tahun 2005-2010 adalah penyiapan sumberdaya manusia (SDM) di mana pembangunan SDM menjadi prioritas pembangunan sebagai kerangka dasar Kabupaten Kutai Timur dalam memiliki pelaku-pelaku pembangunan yang handal yang ditujukan bagi generasi yang akan datang dan juga generasi muda saat ini.

Periode selanjutnya adalah periode pematangan. Dalam periode ini diharapkan masyarakat atau SDM yang telah dibina akan dapat mengembangkan kegiatan ekonomi di mana produksi keluarga dapat menjadi produksi wilayah kemudian produksi menyeluruh.

Tahap terakhir dari skenario jangka panjang adalah periode pemantapan dimana masyarakat dan kota telah menjadi tegar dan maju dalam artian siap dalam melakukan pembaharuan menangkap visi sebagai pusat agribisnis dan agroindustri bagi Kalimantan Timur dan wilayah yang
Sumber RPJMD 2006-2010 dan RPJMD 2011-2012 Kabupaten Kutai Timur

Tabel di atas semakin menegaskan semangat Kabupaten Kutai Timur untuk mandiri (tanpa tambang) melalui formulasi agro bisnis dan agro industry. Namun bila dampak ekstraksi pertambangan tidak diperhitungkan dan tidak diantisipasi sejak dini, maka kabupaten ini justru akan terjebak fenomena kutukan sumber daya alam.

Kutukan SDA adalah istilah yang digunakan untuk menjelaskan kegagalan negara-negara atau daerah kaya sumber alam untuk mengambil manfaat dari berkah kekayaan yang mereka miliki. Gambaran ini terpampang jelas di Afrika. Kongo, Angola dan Sudan diguncang perang saudara, sedangkan Nigeria menderita akibat wabah korupsi ${ }^{32}$,

\footnotetext{
${ }^{32}$ Macartan Humphreys, Jeffrey D. Sachs, dan Joseph E. Stiglitz, 2007. ESCAPING THE RESOURCE CURSE, Columbia University Press
} 
sementara negara-negara yang minim sumber alam dan sama melaratnya seperti Burkina Faso dan Ghana justru bisa hidup damai dan menerapkan pemerintahan demokratis.

Pertimbangan yang sama disampaikan Terry Lynn Karl, ${ }^{33}$ Profesor Pusat Study Amerika Latin di Stanford University ini menegaskan; konsekuensi dari pembangunan yang didasarkan pada ekspor tambang cenderung negatif setidaknya selama 40 tahun terakhir. Efek buruknya menurut Terry meliputi pertumbuhan ekonomi lebih lambat dari yang diharapkan, diversifikasi ekonomi yang buruk, indikator kesejahteraan sosial yang menyedihkan, tingkat kemiskinan dan ketimpangan yang tinggi, kerusakan lingkungan di tingkat lokal, korupsi yang meluas, penyelenggaraan pemerintahan yang sangat buruk, serta tingkat konflik dan perang yang tinggi

Pernyataan Terry dan pertimbangan fenomenaKutukan SDA di atas patut direnungkan dalam rangka antisipasi dampak buruk ekstraksi pertambangan di Kabupaten Kutai Timur, sehingga target skenario pembangunan di atas dapat terealisir.

Pertimbangan-pertimbangan tersebut sekaligus dijadikan fondasi dalam merumuskan program dan kegiatan pemerintah dalam kerangka integrasi pelaksanaan CSR dan perencanaan pembangunan ditiga periode yang telah ditetapkan.

Langkah ini kemudian diikuti dengan menetapkan variabel ukuran

\footnotetext{
${ }^{33}$ Karl, Terry Lynn, 2004. Oil Led Development: Social Economic and Political Consequences, Encyclopedia of Energy vol IV New York: Elsevier
}

keberhasilan pada setiap periode(Perode Pembekalan Dasar 2006-2015, Periode Pematangan 2016-2025, dan Periode Pemantapan 2026-2030) sekaligus mengintegrasikan seluruh sumberdaya pemerintah dan sumber daya perusahaan untuk mendukung pelaksanaan rencana jangka panjang tersebut.

Dengan cara ini perusahaan benar-benar menyatu dengan pemerintah dan rakyat,dan secara sungguh-sungguh melakukan program bersama demi kemajuan bersama. Dengan demikian keseimbangan hidup akan tercipta, sehingga dapat menjamin kelancaran investasi-tanpa gangguan, sebagaimana terjadi dibanyak daerah penghasil tambang.

\section{F. KESIMPULAN}

Model baru pelaksanaan CSR di atas dapat menjadi solusi dari kegagalan CSR dibanyak perusahaan. Konflik yang masih berkecamuk didaerah penghasil tabang, ketidakpuasan masyarakat yang menyeruak seiiring dengan pelaksanaan program CSR merupakan persoalan menahun, dampak dari ketidakseriusan perusahaan dalam melaksanakan konsepsi CSR secara sungguhsungguh.

CSR hanya diberikan pada elit politik dan pemerintahan lokal sehingga melahirkan fenomena yang oleh para pakar disebut sebagai "renziking behaviour" dan koruptorkoruptor baru. CSR juga tak jarang diperuntukkan bagi polisi dan TNI untuk pengamanan perusahaan.

Kalaupun dana CSR dekelola oleh lembaga swadaya masyarakat, 
tak jarang program-programnya kurang tepat sasaran dan kerap berbenturan dengan program pembangunan pemerintah

Disituasi inilah program CSR perlu diintegrasikan ke dalam program perencanaan pembangunan pemerintah, sehingga rakyat melalui media, lembaga swadaya, dan wakilnya di parlemen disatu sisi dapat mengontrol pelaksanaannya.

Disisi lain integrasi di atas dapat menjamin efektifitas, akuntabilitas, dan kebersamaan antara pemerintah, rakyat, dan perusahaan. Harmonisasi inilah yang oleh John Elkington (1998), sang pencetus CSR,disebut sebagai keseimbangan antara planet, people, dan provit.

\section{G. DAFTAR PUSTAKA}

Bob de Wit and Ron Meyer. 2004. Strategy: Process, Content, Context - 3rd Ed. London: Thomson Learning

Dedy N. Hidayat, dalam Eriyanto, 2001. Analisis Wacana Pengantar Analisis Teks Media,LkiS, Yogyakarta

Eriyanto, 2001. Analisis Wacana Pengantar Analisis Teks Media, LkiS, Yogyakarta

Edi. Suharto, 2008 Menggagas Standart Audit CSR, dalam Round Table Discussion AAI

Fairclough N., 2000, ì Discourse, social theory and social research: the discourse of welfare reformî, Journal of Sociolinguistics 4

Karl, Terry Lynn, 2004. Oil Led Development: Social Economic and Political Consequences, Encyclopedia of Energy vol IV New York: Elsevier
Lewis Arthur, 1965. Development Planing, New York, Harper Row

Macartan Humphreys, Jeffrey D. Sachs, dan Joseph E. Stiglitz, 2007. ESCAPING THE RESOURCE CURSE, Columbia University Press

Michel Todaro. 1971. Development Planing: Models and Methods. Nairobi: Oxford University Press

M.L. Jhingan. 1990. Ekonomi Pembangunan dan Perencanaan (terjemahan) Rajawali Press, Jakarta

Pearce and Robinson. 2005. Formulation, Implementation, and Control of Competitive Strategy. New York: McGrawHill Irwin, p; 43. Bandingkan dengan

Syafrizal, 2009. Teknis Praktis Penyusunan Pembangunan Daerah, Baduose Media, Padang

Van Dijk, T. A. 1998. Ideology. A Multidisciplinary Study. London: Sage.

Wodak, R. 2001. What CDA is about - a summary of its history, important concepts, and its development. In Methods of CDA. (ed.) by R. Wodak and M. Meyers. London: Sage Publication.

\section{Paraturan Perundang-undangan}

UU No.19 Tahun 2003 tentang Badan Usaha Milik Negara

Undang-undang Nomor 25 Tahun 2004 tentang Sistem Perencanaan Pembangunan Nasional

UU No 40 Tahun 2007 Tentang Perseroan Terbatas 
UU No 25 Tahun 2007 tentang Penanaman Modal

Peraturan Pemerintah No 47 Tahun 2012 tentang Tanggungjawab Sosial dan Lingkungan Perseroan Terbatas.

Peraturan Mentri Dalam Negeri No 54 Tahun 2010 tentang Tahapan Tatacara Penyusunan, Pengendalian, dan Evaluasi Pelaksanaan Rencana Pembangunan Daerah

Rencana Pembangunan Jangka Panjang Daerah (RPJPD 20062025) Kabupaten Kutai Timur

Rencana Pembangunan Jangka Menengah Daerah (2006-2010) Kabupaten Kutai Timur

Rencana Pembangunan Jangka Menengah Daerah (2011-2015) Kabupaten Kutai Timur

Surat Keputusan Bersama antara Bupati Kutai Timur dan Presiden Direktur KPC No.43/02.188.45/HK/II/2005 tanggal 21 Februari 2005.

Eksekutif Summary AMDAL PT KPC Tahun 2005

Keputusan Bupati Kutai Timur No. 71/02.188.45/HK/III/2006.

Kepengurusan Forum ini terdiri dari Dewan Pengarah (Ketua: Bupari Kutim); Dewan Pelaksana (Ketua: Wakil Bupati dan anggota terdiri dari kalangan Perusahaan, LSM, Pemerintah Kabupaten Kutim dan individu (masyarakat). 